\title{
MAN'S EFFECTS ON AQUATIC AND RIPARIAN ORGANISMS IN THE CANYONS OF CANYONLANDS AND ARChes NaTional PARKS AND NATURAL BRIDGE NATIONAL MONUMENT
}

\author{
SANDRA MITCHELL $\bullet$ DEPARTMENT OF BIOLOGY \\ WESTERN WYOMING COLLEGE $\bullet$ ROCK SPRINGS \\ BRUCE WOODWARD $\uparrow$ DEPARTMENT OF BIOLOGY \\ UNIVERSITY OF NEW MEXICO $\bullet$ ALBUQUERQUE
}

\section{$\checkmark$ EXECUTIVE SUMMARY}

This research was designed to assess the impact of a hiking trail or a four wheel drive road on our three focal groups (plants, aquatic animals and small mammals). Analyses in 1990 revealed large differences in species abundances and some instances of presence/absence differences among the three focal groups. Differences occurred both between the road right of way per se and nonroaded sections of the canyon bottom and between roaded and nonroaded sections of the canyon bottom. In 1990 we sampled small mammals and plants for $2.4 \mathrm{~km}$ up and downstream of the road terminus. In May, June, and July 1991 we extended sampled areas to approximately $4.8 \mathrm{~km}$ up and downstream of the end of the four wheel drive road. We also sampled aquatic organisms at Natural Bridges and in Canyonlands. In addition, we performed an experiment in which we placed screen mesh enclosures into the creek above and below Bates Wilson Campground, Canyonlands. This experiment was designed to assess sand infiltration rates and aquatic animal densities in areas lacking or possessing a road. Four small mammal trap grids (70 traps/grid) were trapped in the area lacking a road and in an area containing a road up Salt Creek. Each trap grid was trapped for four successive nights.
Eight plant grids (4 up and 4 downstream of the road terminus) were examined for species composition and plant coverages. Each upstream grid consisted of fifty $1 \mathrm{~m}^{2}$ plots, while the downstream grids consisted of the same 50 plots plus 10 plots randomly located in the road right of way.

Data analyses for 1991 are not yet complete but our subjective impression is that the 1991 results will duplicate those obtained in 1990 . The hiking trail at Natural Bridges appears to influence the distribution and abundance of aquatic animals, perhaps by increasing the amount of sand entering the stream channel. In the area containing the trail, pools have a sandy substrate and contain many sand living organisms like mayflies. Conversely, in the area immediately upstream of the trail, pools have a rocky substrate and are occupied primarily by organisms that live between or on the surface of rocks like snails and caddisflys. At Canyonlands in 1990 we observed differences in species abundances for plants, aquatic animals and small mammals between areas containing or lacking a road in Salt Creek Canyon. Our subjective impression is that further sampling in these areas in 1991 has revealed similar patterns. We are currently in the process of analyzing these data sets. 